\title{
Thyroidea Ima Artery: A Report of Two Cases
}

\section{${ }^{1}$ Sagaya Raj, ${ }^{2}$ Azeem Mohiyuddin, ${ }^{3}$ Shuaib Merchant, ${ }^{4}$ Rijo M Jayaraju, ${ }^{5}$ Beauty Sasidharan}

\section{ABSTRACT}

Thyroidea ima is a rare anomalous artery supplying the thyroid gland apart from the superior and inferior thyroid arteries. It is of surgical importance in thyroid, parathyroid and tracheal surgeries.

Our study aims to highlight two cases of thyroidea ima artery found during thyroidectomy:

- Case 1: Thyroidea ima artery was seen arising from the medial surface of the right common carotid artery in a female patient, who underwent total thyroidectomy.

- Case 2: Thyroidea ima artery was seen arising from the anterior surface of the right innominate artery, in a female patient, who underwent right hemithyroidectomy.

Conclusion: Thyroidea ima artery, although a rare arterial variation, a thorough regional anatomic knowledge and meticulous dissection will not only help us in identifying such a vascular variation, also help us in preventing an accidental injury.

Keywords: Thyroidea ima, Thyroidectomy, Anomalous blood vessels.

How to cite this article: Raj S, Mohiyuddin A, Merchant S, Jayaraju RM, Sasidharan B. Thyroidea Ima Artery: A Report of Two Cases. Int J Head Neck Surg 2014;5(2):89-90.

Source of support: Nil

Conflict of interest: None

\section{INTRODUCTION}

Thyroidea ima is a rare anomalous artery supplying the thyroid gland apart from the superior and inferior thyroid arteries. They most commonly arise from the innominate, aortic arch, right common carotid or subclavian artery. The presence of this artery is of surgical significance in thyroid, parathyroid and tracheal surgeries.

\section{AIM}

This study aims to highlight two cases in whom, thyroidea ima artery was found originating from different sites during thyroidectomy.

\footnotetext{
${ }^{1}$ Associate Professor, ${ }^{2}$ Professor and Head, ${ }^{3}$ Lecturer

${ }^{4,5}$ Postgraduate Student

${ }^{1}$ Department of ENT, Sri Devaraj Urs Medical College, Kolar Karnataka, India

${ }^{2-5}$ Department of Otolaryngology and Head and Neck Surgery Sri Devaraj Urs Medical College, Kolar, Karnataka, India
}

Corresponding Author: Sagaya Raj, Associate Professor Department of ENT, Sri Devaraj Urs Medical College, Kolar Karnataka, India, Phone: 08153271798, e-mail: sagayaraj79@ gmail.com

\section{MATERIALS AND METHODS}

We routinely dissect and expose the common carotid artery before mobilizing the thyroid gland (lateral to medial approach). By this approach, a good vascular control is achieved and inadvertent injury to blood vessels is avoided even if the thyroid gland is large and extending retrosternal. The three structures of significance between common carotid and trachea are the recurrent laryngeal nerve, inferior thyroid artery and middle thyroid vein. Any anomalous vessel in this location can be easily identified and dissected to its origin thereby avoiding injury.

In our experience in the two cases mentioned, the thyroidea ima artery was found to be arising from right common carotid artery in case 1 and right innominate artery in case 2 which was meticulously dissected and ligated.

\section{CASE REPORTS}

\section{Case 1}

In a 45-year-old lady who underwent total thyroidectomy for multinodular goiter. The thyroidea ima artery was seen arising from the right common carotid artery coursing over the anterior surface of trachea to supply the lower pole of the thyroid gland. The inferior thyroid artery on the right side had a normal course (Fig. 1).

\section{Case 2}

A 27-year-old lady who underwent right hemithyroidectomy for solitary nodule. The thyroidea ima artery was seen arising from the anterior surface of the right innominate artery and

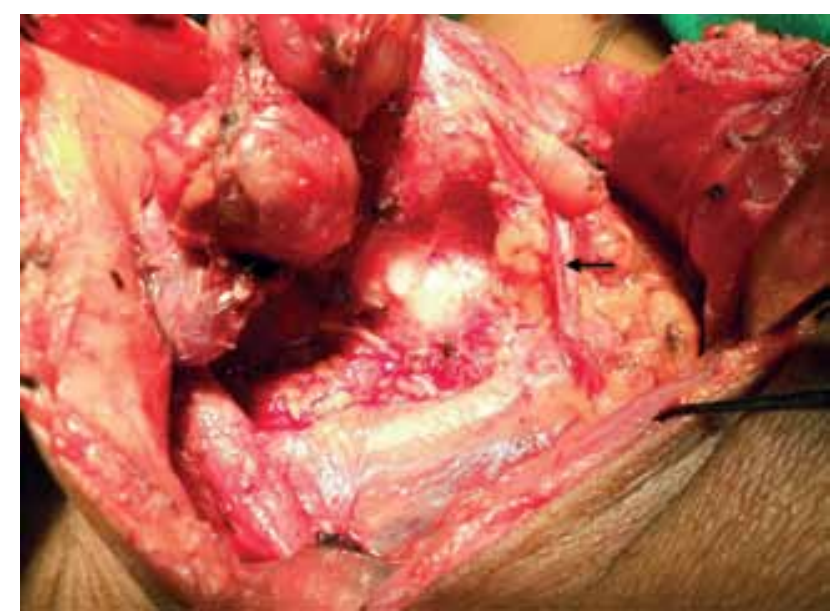

Fig. 1: Thyroidea ima artery (marked with arrow) on right side arising from the right common carotid artery coursing over the anterior surface of trachea to supply the lower pole of the thyroid gland 


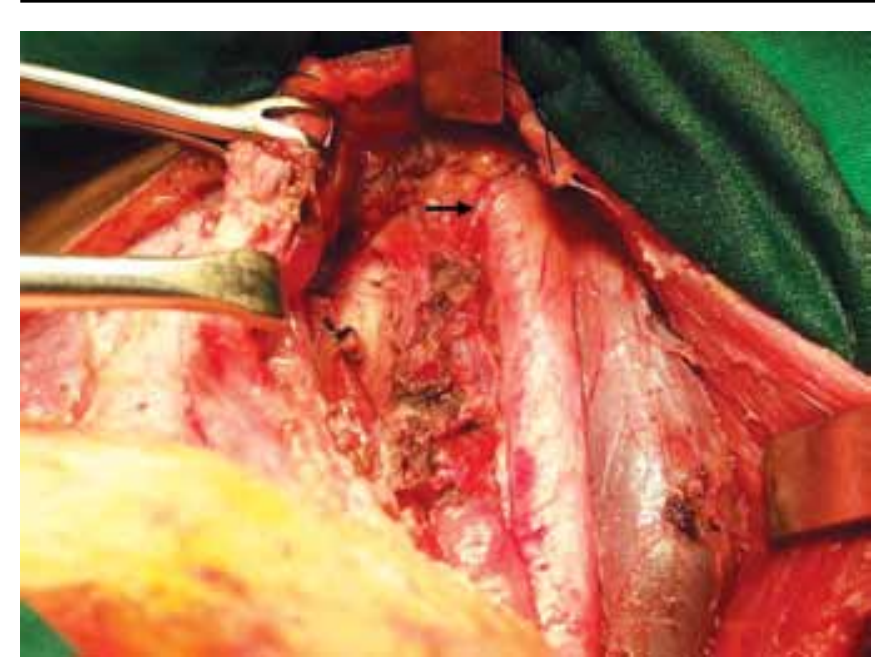

Fig. 2: Thyroidea ima artery (marked with arrow) arising from the anterior surface of the right innominate artery and coursing superiorly to the lower pole of the thyroid gland

coursing superiorly to the lower pole of thyroid gland with a normal course of the inferior thyroid artery (Fig. 2).

\section{DISCUSSION}

Any anomalous artery supplying the thyroid, either accessory to, or instead of the inferior thyroid artery has been identified as thyroidea ima artery. Thyroidea ima artery has a variable frequency of occurrence, site of origin and description. ${ }^{1}$

First described by Neubauer in 1772 , hence it is also called thyroid artery of Neubauer. ${ }^{2}$ The incidence of thyroidea ima artery is 1.5 to $12.2 \%$. There are not many clinical studies on this artery, as they are rarely reported. The origin of thyroidea ima in literature is variable, most commonly from the innominate in 1.9 to $10.6 \%$, right common carotid in 1.4 to $1.7 \%$ and arch of aorta in $0.36 \% .{ }^{3}$ Very rarely, it may arise from the subclavian artery. ${ }^{1}$

Phylogenetically, thyroidea ima artery is presumed to be due to persistence of original vascular network connecting brachiocephalic, aortic arch and carotids which by fusion may either supplement or substitute the regular blood supply of the thyroid gland, namely the superior and inferior thyroid arteries. ${ }^{1}$

Thyroidea ima artery is of surgical importance during thyroid, parathyroid, tracheal and mediastinal surgeries as there can be injury to these vessels causing significant hemorrhage. Therefore, a good anatomical knowledge of anomalous vessels and a meticulous dissection are mandatory to avoid injury to these vessels.

\section{CONCLUSION}

Thyroidea ima artery, though a rare anatomical variation can pose a risk for inadvertent injury and hemorrhage to a nonsuspecting surgeon. A good knowledge of regional anatomy and the vascular variations, and a meticulous systematic dissection would help in identifying these variations and also in prevention of accidental vascular injury.

\section{REFERENCES}

1. Dharwal K. The thyrothymic Trunk: a collateral vessel to the thyroid and the thymus. People's J Scientific Research 2009;2(2): 31-33.

2. Krudy AG, Doppman JL, Brennan F. The significance of the thyroidea ima artery in angiographic localization of parathyroid adenomas. Radiology 1980;136(1):51-55.

3. Hollinsheads WH. Head and Neck. In: Anatomy for Surgeons. 1st ed. New York: Hober and Harper; 1962.p.520-533. 